\title{
Analisis Faktor-Faktor yang Mempengaruhi Nilai Perusahaan dengan Kualitas Laba sebagai Moderasi
}

\author{
Wasininingsih ${ }^{1}$, JMV Mulyadi ${ }^{2}$ \\ 1, 2 Universitas Pancasila, Jakarta, Indonesia
}

INFO ARTIKEL

JEL Classification :

M41, G32

Keywords :

profitability,liquidity,

leverage,ownership

structure, company value

\begin{abstract}
This study aims to determine the effect of profitability, liquidity, leverage, ownership structure on firm value with earnings quality as moderation in Real Estate companies. Object of research of Real Estate companies listed on the Indonesia Stock Exchange in the 2014-2018 period. The samples in this study were 28 Real Estate companies on the Indonesia Stock Exchange. Data used secondary data. The analytical method used in this study is PLSSEM with WarpPLS 5.0. the results showed profitability, liquidity did not affect the value of the company. Leverage affects the value of the company. Earnings quality does not moderate the ownership structure.
\end{abstract}

\begin{abstract}
ABSTRAK
Penelitian ini bertujuan untuk mengetahui pengaruh profitabilitas, likuiditas, leverage, struktur kepemilikan terhadap nilai perusahaan dengan kualitas laba sebagai moderasi pada perusahaan Real Estate. Obyek penelitian perusahaan Real Estate yang terdaftar di Bursa Efek Indonesia periode 2014-2018. Sampel dalam penelitian ini 28 perusahaan Real Estate di Bursa Efek Indonesia. Data digunakan data skunder. Metode analisis yang digunakan dalam penelitian ini PLS-SEM dengan WarpPLS 5.0. hasil penelitian menunjukan profitabilitas, likuiditas tidak berpengaruh terhadap nilai perusahaan. Leverage berpengaruh terhadap nilai perusahaan. Kualitas laba tidak memoderasi struktur kepemilikan.
\end{abstract}

\section{Pendahuluan}

Era globalisasi dan teknologi saat ini di dunia bisnis mengalami persaingan yang sangat ketat, khususnya perusahaan real estate. Perusahaan real estate dituntut untuk meningkatkan keunggulan produknya guna untuk meningkatkan daya saing. Menurut (Dewi \& Wirajaya, 2013), nilai perusahaan merupakan nilai pasar dari suatu equitas perusahaan ditambah dengan nilai pasar utang. Perusahaan sebagai suatu entitas yang beroperasi dengan menerapkan prinsipprinsip ekonomi, umumnya tidak hanya berorientasi pada pencapaian laba maksimal, melainkan juga ingin meningkatkan nilai perusahaan dan kemakmuran pemilik atau pemegang saham.

Nilai perusahaan yang diproksikan price earning ratio menurut (Sartono, 2001), harga saham merupakan nilai yang dimiliki individu atau investor didalam sebuah perusahaan. semakin tinggi harga saham menunjukan bahwa kinerja yang dimiliki perusahaan tentu akan semakin baik begitu juga sebaliknya. Untuk mengambil keputusan investasi membeli ataupun menjual maka dapat dilakukan dengan menghitung nilai price earning ratio ( PER). 
Fenomena terus meningkatnya harga saham dari tahun 2014-2018 yang terdaftar di indeks harga saham gabungan (IHSG) menjadi hal yang menarik untuk diamati.

Berdasarkan rata-rata $P E R$ selama 5 tahun terakhir, yaitu tahun 2014 sebesar 31,42, sedangkan tahun 2015 naik sebesar 301,35, untuk tahun 2016 naik sebesar 432,71, sedangkan tahun 2017 naik sebesar 978,87, untuk tahun 2018 naik sebesar 1.386,32.

Untuk mendukung fenomena penelitian diulas pula research gap penelitian terdahulu. Penelitian (Alia,2013) menerangkan bahwa variabel profitabilitas yang diproksikan dengan ROE berpengaruh signifikan positif terhadap nilai perusahaan, apabila profitabilitas meningkat maka nilai perusahaan juga meningkat, sedangkan penelitian (Prasetyorini,2013) menerangkan profitabilitas tidak berpengaruh terhadap nilai perusahaan.

Penelitian (Dewi, Andini, \& Santoso, 2018) dan (Prisila, 2013) mengemukakan bahwa likuiditas berpengaruh positif terhadap nilai perusahaan. Semakin baik kemampuan perusahaan untuk melunasi kewajiban berarti semakin kecil risiko likuiditas yang dialami perusahaan. Sedangkan penelitian (Sambora,2014) menerangkan bahwa likuiditas tidak berpengaruh terhadap nilai perusahaan. Seorang investor dalam berinvestasi tidak hanya menginginkan keuntungan yang akan digunakan sebagai modal lagi untuk membesarkan perusahaan tersebut.

Penelitian (Sambora,2014) dan (Ogolmagai,2013) menerangkan bahwa leverage yang diproksikan DAR tidak berpengaruh terhadap nilai perusahaan, sedangkan penelitian (Ekadjaja,2017) dan (Petrus,2016) menerangkan DAR berpengaruh terhadap nilai perusahaan.

Penelitian (Wardani,2011) menerangkan bahwa struktur kepemilikan berpengaruh terhadap nilai perusahaan. Semakin tinggi struktur kepemilikan dalam bentuk kepemilikan istitusional semakin tinggi juga ROA nya. Sedangkan penelitian (Hidayah, 2015) menerangkan bahwa struktur kepemilikan tidak mempengaruhi nilai perusahaan. Hal ini perusahaan memberikan kesejahteraan bagi pemilik saham atau investor tanpa mempertimbangkan adanya kepemilikan saham.

\section{Telaaah Teori dan Pengembangan Hipotesis}

\section{Profitabilitas dan nilai perusahaan}

Profitabilitas yang diproksikan dengan ROE menunjukan kemampuan perusahaan untuk menghasilkan laba setelah pajak dengan menggunakan modal sendiri. Dari hasil penelitian Sari (2013), Jahirul (2010), Dewi (2013), Ria (2015), Rahmawati (2015), Kurniawan (2018), Wijaya (2013) mengungkapkan bahwa profitabilitas yang di proksikan dengan ROE mempengaruhi nilai perusahaan.

\section{$H_{1}$ : profitabilitas berpengaruh terhadap nilai perusahaan.}

\section{Likuiditas dan nilai perusahaan}

Likuiditas menunjukan besarnya kewajiban lancar yang ditutup dengan aktiva yang diharapkan akan dikonversi menjadi kas dalam jangka pendek. Menurut Sudana (2011) perusahaan dikatakan likuid apabila perusahaan mampu memenuhi kewajiban jangka pendeknya dengan aktiva lancar yang dimiliki.

\section{$\mathrm{H}_{2}$ : likuiditas berpengaruh terhadap nilai perusahaan.}

\section{Leverage dan nilai perusahaan}

Leverage merupakan perbandingan antara jumlah hutang jangka panjang dengan modal sendiri atau ekuitas dalam pendanaan perusahaan. Berarti semakin tinggi nilai rasio ini akan semakin sedikit modannya daripada hutangnnya. Artinya besar kecilnya leverage selalu diikuti besar kecilnya resiko pula sehingga berpengaruh baik positif terhadap nilai perusahaan. penjelasan tersebut didukung oleh penelitian Linawati \& Ekadjaja ( 2017), sedangkan penelitian Petrus (2016) menerangkan leverage tidak berpengaruh terhadap nilai perusahaan.

\section{$\mathrm{H}_{3}$ : leverage berpengaruh terhadap nilai perusahaan}

Struktur kepemilikan dan nilai perusahaan

Struktur kepemilikan merupakan sebuah lembaga yang memiliki kepentingan besar terhadap investasi yang dilakukan termasuk 
investasi saham. Penjelasan tersebut didukung oleh (Dewi et al., 2018) dan (Pratama \& Wirawati, 2016)) bahwa struktur kepemilikan berpengaruh terhadap nilai perusahaan.

\section{$\mathrm{H}_{4} \mathrm{a}$ : Struktur kepemilikan berpengaruh terhadap nilai perushaan}

\section{$\mathrm{H}_{4} \mathrm{~b}$ : Kualitas laba berpengaruh terhadap nilai perusahaan.}

\section{Metode Penelitian}

Populasi penelitian ini yaitu perusahaan real estate berjumlah 48 perusahaan yang terdaftar di Bursa Efek Indonesia periode 2014-2018.

Desain penelitian adalah hubungan sebabakibat (kausatif), yaitu suatu metode yang menjelaskan pengaruh variabel independen terhadap variabel dependen dengan diperkuat atau diperlemah oleh variabel pemoderating. Operasional Variabel.

a. Nilai perusahaan, yang diproksikan Price Earning Ratio (PER) :

$$
P E R=\frac{\text { harga perlembar saham }}{\text { laba perlembar saham }} \times 100 \%
$$

b. Profitabilitas, yang diproksikan Return On Equity ( $R O E$ ):

$$
\mathrm{ROE}=\frac{\text { laba bersih }}{\text { total equity }} \times 100 \%
$$

c. Likuiditas, yang diproksikan current ratio $(C R)$ :

$$
\mathrm{CR}=\frac{\text { aset lancar }}{\text { kewajiban lancar }} \times 100 \%
$$

d. Leverage, yang diproksikan dept tp ratio $(D R)$ :

$$
\mathrm{DR}=\frac{\text { total utang }}{\text { total aktiva }}
$$

e. Struktur kepemilikan, yang diproksikan kepemilikan institusional ( KI): $\mathrm{KI}=\frac{\text { jumlah saham dimiliki insider }}{\text { total sahan beredar }}$ f. Kualitas laba, diproksikan discretionary accrual ( $D A)$ :

$D A=T A C C_{i t}-N D A C C_{I T}$

Model persamaan dalam persamaan ini adalah:

$\mathrm{PER}=\alpha+\beta 1 \mathrm{ROE}+\beta 2 \mathrm{CR}+\beta 3 \mathrm{DR}+\beta 4 \mathrm{KI}+\beta 5 \mathrm{DA}+$ $\beta 6 \mathrm{KI} * \mathrm{DA}+\alpha \mathrm{ROA}+\alpha \mathrm{TATO}+\mathrm{e}$

dimana :

PER $=$ Price Earning Ratio

$\mathrm{ROE}=$ Return On Equity

$\mathrm{CR}=$ Current Ratio

$\mathrm{DR}=$ Debt To Ratio

KI = Kepemilikan Institusional

DA = Discreonarity Accrual

ROA $=$ Return On Asset

TATO $=$ Total Aset Tur Nover

$\alpha \quad=$ Konstanta

$\beta 1-\beta 6=$ Koefisien Regresi

e $=$ error

\section{Hasil Penelitian dan Pembahasan}

\section{Hasil Penelitian}

\section{Analisis Statistik Deskriptif}

Teknik analisis data dalam penelitian ini yaitu metode Struktur Equation Modeling (SEM) dengan pendekatan Partial Least Square (PLS) dan analisis multigrup menggunakan WarpPLS 5.0.

Uji inner model

- Model Fit and quality indices

- Model fit indices

- Model output nilai signifikansi dan koefisien jalur

- Hasil uji hipotesis

- Uji parsial

- Rangkuman uji hipotesis 
Tabel 4.1. Deskripsi Variabel

\begin{tabular}{lrrrrr}
\hline \multicolumn{1}{c}{ Variabel } & N & Minimum & Maksimum & \multicolumn{1}{c}{ Mean } & Standar Deviasi \\
\hline Nilai perusahaan & 28 & 0.760 & 110664.990 & 168.886 & 990.226 \\
Prifitabilitas & 28 & 0.120 & 52.430 & 11.749 & 8.736 \\
Likuiditas & 28 & 0.070 & 13.260 & 2.992 & 2.739 \\
Leverage & 28 & 0.070 & 21.000 & 0.956 & 2.893 \\
Struktur kepemilikan & 28 & 0.050 & 0.880 & 0.541 & 0.247 \\
Kualitas laba & 28 & -16361005 & 59969361 & -41656187 & 15382671 \\
Prifitabilitas & 28 & 0.100 & 19.590 & 6.331 & 4.616 \\
Perputaran Asset & 28 & 0.012 & 1.205 & 0.227 & 0.151 \\
\hline Sub
\end{tabular}

Sumber: data diolah, 2019 ( Output WarpPLS 5.0 )

Berdasarkan Tabel 4.1 hasil output diatas dapat dilihat bahwa jumlah perusahaan yang $\mathrm{d}$ ijadikan sampel ada 28 perusahaan real estate yang diperoleh dari tahun 2014-2018. Nilai perusahaan dengan nilai minimal 0,760 dimiliki oleh perusahaan Pikko Land Development Tbk ( RODA) tahun 2015. Maksimal 11064.990 pada perusahaan Megapolitan Development Tbk(EMDE) pada tahun 2017. Nilai rata-rata sebesar 168886 dan nilai standar deviasi sebesar 990226.

Profitabilitas nilai minimal sebesar 0.120 pada perusahaan Bekasi Asri Pemula Tbk (BAPA) tahun 2014, nilai maksimal 52.43 pada perusahaan Bekasi Asri Pemula $\mathrm{Tb}$ (BAPA) pada tahun 2015, sedangkan nilai rata-rata sebesar 11.749 dan standar deviasi sebesar 8.736.

Variabel likuiditas yang diproksikan current ratio ( $\mathrm{CR}$ ) nilai minimum sebesar 0.070 dimiliki perusahaan Alam Sutera Tbk 9 ASRI) pada tahun2017, sedangkan nilai maksimum sebesar 13.260 dimiliki perusahaan Metropolitan Kenjana Tbk
(MKPI) pada tahun 2016. Untuk rata-rata 2.922 sedangkan standar deviasinya sebesar 2.739 .

Variabel Leverage yang diproksikan dengan debt to asset ratio( DAR) nilai minimum sebesar 0.070 dimiliki oleh perusahaan Ciputra Development Tbk (CITRA) pada tahun 2017, sedangkan nilai maksimum sebesar 21.000 dimiliki oleh perusahaan Bumi Serpong Damai Tbk (BSDE) pada tahun 2014. Untuk rata-rata sebesar 0.956, sedangkan standar deviasi sebesar 2.893 .

Variabel struktur kepemilikan yang diproksikn dengan kepemilikan institusional (KI) memiliki nilai minimum sebesar 0.050 dimiliki oleh perusahaan Megapolitan Development Tbk (EMDE) pada tahun 2014, sedangkan untuk nilai maksimum sebesar 0.880 dimiliki oleh perusahaan Bumi Serpong Damai Tbk (BSDE) pada tahun 2016. Untuk rata - rata sebesar 0.541 dan untuk standar deviasi sebesar 0.247 .

Tabel 4.2 Hasil Pengujian Hipotesis

\begin{tabular}{lccc}
\hline Variabel & Nilai koefisien & p. value & Keterangan \\
\hline H1:ROE->PER & -0.007 & 0.467 & Tidak Signifikan \\
H2:CR-PPER & -0.015 & 0.429 & Tidak Signifikan \\
H3:DR->PER & 0.685 & $<0.001$ & Signifikan \\
H4:KI->PER & 0.029 & 0.364 & Tidak Signifikan \\
& & & \\
Uji Interaksi & & & \\
H5:KI:DA->PER & -0.022 & 0.397 & Tidak Signifikan \\
\hline
\end{tabular}




\section{Pembahasan}

Berdasarkan analisis dapat diperoleh hasil nilai $\mathrm{R} 2=58,60 \%$. Sehingga dapat ditarik kesimpulan bahwa profitabilitas, likuiditas, leverage dan kepemilikan institusional mampu menjelaskan pengaruhnya terhadap nilai perusahaan sebesar $58,60 \%$ sedangkan $41,40 \%$ dipengaruhi oleh variabel lain diluar model penelitian.

1. Profitabilitas yang diproksikan dengan return on equity (ROE) tidak mempengaruhi terhadap nilai perusahaan, berdasarkan hasil uji hipotesis didapatkan nilai Sig $0.467>0.05$ menghasilkan kesimpulan bahwa profitabilitas (ROE) tidak berpengaruh terhadap nilai perusahaan. berdasarkan teori sinyal profitabilitas bukan memberikan sinyal yang positif terhadap nilai perusahaan, dikarenakan perusahaan tidak hanya menginginkan keuntungan semata tetapi juga melihat nilai perusahaannya.

2. Likuiditas yang diproksikan dengan current ratio (CR) tidak berpengaruh terhadap nilai perusahaan, berdasarkan hasil uji hipotesis didapatkan nilai Sig $0.429>0.05$ menghasilkan kesimpulan bahwa likuiditas ( CR) tidak berpengaruh terhadap nilai perusahaan. investor jangka dalam berinvestasi tidak hanya menginginkan keuntungan yang akan digunakan sebagai modal lagi untuk membesarkan perusahaan tersebut.

3. Leverage yang diproksikan dengan Dept to ratio (DR) berpengaruh terhadap nilai perusahaan, berdasarkan hasil uji hipotesis didapatkan nilai Sig $0.001>0.05$ menghasilkan kesimpulan bahwa leverage berpengaruh terhadap nilai perusahaan. , sinyal yang positif bagi perusahaan, leverage yang dimiliki perusahaan menjadi pertimbangan yang penting diambil investor dalam berinvestasi.

4. Struktur kepemilikan yang diproksikan dengan kepemilikan institusional (KI) tidak berpengaruh terhadap nilai perusahaan, berdasarkan hasil uji hipotesis didapatkan nilai Sig $0.364>0.05$ menghasilkan kesimpulan bahwa struktur kepemilikan tidak berpengaruh terhadap nilai perusahaan. kepemilikan istitusional kurang efektif sebagai alat memonitor manajemen dalam meningkatkan nilai perusahaan, pimpinan terkadang melakukan tindakan yang luput dari pengawasan pemegang saham institusi.

\section{Kesimpulan}

Berdasarkan hasil analisis data dan pembahasan penelitian yang sudah dilakukan pada bab sebelumnya, maka dapat ditarik kesimpulan sebagai berikut, antara lain :

1. Profitabilitas yang diproksikan ROE tidak berpengaruh terhadap nilai perusahaan pada perusahaan real estate yang terdaftar di BEI Tahun2014-2018. Hal ini dikarenakan ROE mengukur tingkat profitabilitas perusahaan dengan menghitung berapa banyak jumlah keuntungan perusahaan yang dihasilkan dari dana yang diinvestasikan oleh para pemegang saham. Perhitungannya dengan membagi laba bersih dengan jumlah ekuitas.

2. Likuiditas yang diproksikan dengan $\mathrm{CR}$ tidak berpengaruh terhadap nilai perusahaan pada perusahaan real estate yang terdaftar di BEI Tahun2014-2018. Likuiditas menunjukan kemampuan perusahaan untuk dapat melunasi hutanghutangnya yang sudah jatuh tempo. Apabila perusahaan menggunakan hutang, maka perusahaan harus membayar beban bunga. Bunga merupakan biaya yang harus dibayar, berapapun laba yang diperoleh perusahaan. semakin tinggi tingkat likuiditas perusahaan menunjukan semakin tinggi tingkat kepercayaan investor terhadap perusahaan.

3. Leverage yang diproksikan dengan DAR berpengaruh signifikan positif terhadap nilai perusahaan pada perusahaan real estate yang terdaftar di BEI Tahun20142018. Hasil ini mengindikasikan bahwa leverage yang dimiliki perusahaan menjadi suatu pertimbangan penting yang diambil oleh investor dalam berinvestasi, hal ini dikarenakan peningkatan leverage didalam 
perusahaan dianggap sebagai signal positif bagi perusahaan dalam melakukan investasi perusahaan dimasa yang akan datang, dengan harapan pendapatan perusahaan akan meningkat.

4. Struktur kepemilikan yang diproksikan dengan KI tidak berpengaruh terhadap nilai perusahaan pada perusahaan real estate yang terdaftar di BEI Tahun 20142018. Manajer yang memiliki kepemilikan saham mampu mengelola kinerja keuangan perusahaan dengan baik. Semakin tinggi struktur kepemilikan dalam bentuk kepemilikan institusional semakin tinggi juga rasio return on asset.

5. Kualitas laba tidak memoderasi kepemilikan institusional terhadap nilai perusahaan pada perusahaan real estate yang terdaftar di BEI Tahun2014-2018. Hasil ini jelas bertentangan dengan teori yang ada. Sama halnya dengan kepemilikan manajerial, tidak semua pemilik saham institusional menginginkan investasi yang tinggi, karena mereka juga menginginkan kesejahteraan melalui pembayaran dividen. Sedangkan investasi akan mengurangi dividen yang akan diterima. Walaupun perannya di dalam perusahan sebagai kontroling, tetapi tidak menutup kemungkinan para pemilik institusional akan mementingkan kepentingan institusinya dibandingkan dengan kepentingan perusahaan. tingginya kepemilikan oleh institusi akan meningkatkan pengawasan terhadap perusahaan. pengawasan yang tinggi akan meminimalisasi tingkat penyelewengan penyelewengan yang dilakukan oleh pihak manajemen yang akan menurunkan nilai perusahaan.

Penelitian ini mempunyai beberapa kelemahan yang dapat dijadikan gambaran untuk penelitian berikutnya :

1. Perusahaan yang diteliti hanya terbatas pada perusahaan real estate saja, masih banyak perusahaan yang lain yang listing di BEI.

2. Penelitian ini hanya terfokus pada beberapa variabel saja, antara lain profitabilitas , likuiditas, leverage, kepemilikan institusional.

Penelitian ini masih memiliki banyak keterbatasan, diantaranya adalah :

1. Penelitian ini hanya terfokus pada beberapa variabel saja, sedangkan variabel lain yang terkait dengan nilai perusahaan relatif banyak, antara lain kepemilikan manajerial, kinerja keuangan, faktor fundamental, resiko sistematik, sehingga akan menghasilkan hasil yang berbeda.

2. Penelitian selanjutnya dapat menggunakan variabel moderasi lain selain kualitas laba, karena dalam penelitian ini kualitas laba tidak memoderasi kepemilikan institusional terhadap nilai perusahaan. Variabel moderasi yang digunakan yaitu seperti resiko bisnis, kualitas audit, kebijakan deviden, sehingga hasilnya akan lebih baik lagi.

\section{Daftar Pustaka}

Adita, A., \& Mawardi, W. (2018). Pengaruh Struktur Modal, Total Assets Turnover, Dan Likuiditas Terhadap Nilai Perusahaan Dengan Profitabilitas Sebagai Variabel Intervening (Studi Empiris pada Perusahaan Real Estate dan Properti yang Terdaftar di BEI Periode 20132016) (Doctoral dissertation, Fakultas Ekonomika dan Bisnis).

Prasetyorini, F., \& Fitri, B. (2013). Pengaruh ukuran perusahaan, leverage, price earning ratio dan profitabilitas terhadap nilai perusahaan. Jurnal Ilmu Manajemen (JIM), l(1).

Dewi, N., Andini, R., \& Santoso, E. B. (2018). Pengaruh Likuiditas Dan Pertumbuhan Perusahaan Terhadap Nilai Perusahaan Dengan Variabel Struktur Modal Sebagai Variabel Intervening (Strudi Kasus Pada Perusahaan Property Dan Real Estate Yang Terdaftar Di BEI Periode Tahun 2012-2016). Journal Of Accounting, 4(4).

Dewi, A. S. M., \& Wirajaya, A. (2013). Pengaruh Struktur Modal, Profitabilitas Dan Ukuran Perusahaan Pada Nilai 
Perusahaan. E-Jurnal Akuntansi Universitas Udayana, 42, 358-372. https://doi.org/10.1111/j.17481716.2008.01865.x.

Rompas, G. P. (2013). Likuiditas Solvabilitas Dan Rentabilitas Terhadap Nilai Perusahaan Bumn Yang Terdaftar Dibursa Efek Indonesia. Jurnal EMBA: Jurnal Riset Ekonomi, Manajemen, Bisnis dan Akuntansi, 1(3).

Hasnawati, S., \& Sawir, A. (2015). Keputusan keuangan, ukuran perusahaan, struktur kepemilikan dan nilai perusahaan publik di Indonesia. Jurnal Manajemen dan Kewirausahaan, 17(1), 65-75.

Ogolmagai, N. (2013). Leverage pengaruhnya terhadap Nilai Perusahaan pada industri manufaktur yang go public di Indonesia. Jurnal EMBA: Jurnal Riset Ekonomi, Manajemen, Bisnis dan Akuntansi, 1(3).

Petrus, N. (2016). Pengaruh Debt To Asset Ratio Dan Return On Asset Terhadap Nilai Perusahaan Pt Medco Energi Internasional, Tbk. Dan Entitas Anak. Fin-Acc (Finance Accounting), 1(6).

Wulandari, N., Mardani, R. M., \& Wahono, B. (2018). Pengaruh Struktur Kepemilikan Dan Keputusan Keuangan Terhadap Nilai Perusahaan: Profitabilitas Sebagai Variabel Moderating (Studi Kasus Pada Perusahaan Perbankan ynag terdaftar di Bursa Efek Indonesia tahun 2014-2016). Jurnal Ilmiah Riset Manajemen, 7(02).

Syapruddin, N. A. P., \& Prasetianingrum, S. (2017). Analisis Investasi Dan Kualitas Laba Terhadap Nilai Perusahaan (Studi Empirik Pada Perusahaan Manufaktur yang terdaftar diBursa Efek Indonesia Periode Tahun 2010-2014). Future: Jurnal Manajemen dan Akuntansi, 4(2), 215-233.

Sambora, M. N. (2014). Pengaruh Leverage dan Profitabilitas Terhadap Nilai Perusahaan (Studi pada Perusahaan Food and Beverages yang Terdaftar di BEI
Periode Tahun 2009-2012). Jurnal Administrasi Bisnis, 8(2).

Faza, M. F., \& Hidayah, E. (2015). Pengaruh intellectual capital terhadap profitabilitas, produktivitas, dan nilai perusahaan pada perusahaan perbankan yang terdaftar di Bursa Efek Indonesia (BEI). Ekbisi, 8(2).

Latan, H., \& Ghozali, I. (2017). Partial Least Squares: Konsep, Metode dan Aplikasi menggunakan Program WarpPLS 5.0 (Third Edit). Semarang: Badan Penerbit Universitas Diponegoro.

Dewi, L. C., \& Nugrahanti, Y. W. (2017). Pengaruh Struktur Kepemilikan dan Dewan Komisaris Independen terhadap Nilai Perusahaan (Studi pada Perusahaan Industri Barang Konsumsi di Bei Tahun 2011-2013).

Linawaty, L., \& Ekadjaja, A. (2017). Analisis pengaruh leverage terhadap nilai perusahaan dengan kepemilikan manajerial dan arus kas bebas sebagai variabel pemoderasi. Jurnal Ekonomi, 22(1), 164176.

Rahmawati, S. H. (2015). Analisis Faktorfaktor yang Mempengaruhi Nilai Perusahaan (Studi Empiris pada Perusahaan-Perusahaan yang Terdaftar di Bei Tahun 2010-2012. Jurnal Online Mahasiswa Fakultas Ekonomi Universitas Riau, 2(1).

Gamayuni, R. R. (2014). Relevansi Kinerja Keuangan, Kualitas Laba, Intangible Asset, dengan Nilai Perusahaan. Trikonomika Journal, 11(2), 119-136.

Ang, R. (1997). Buku Pintas Passar Modal Indonesia ( The Intelligent Guide To Indonesia Capital Market). Jakarta: Mediasoft Indonesia.

Siahaan, B. T. (2017). Pengaruh Analisis Rasio Keuangan Terhadap Nilai Perusahaan Dengan Financial Distress Sebagai Variabel Intervening Pada Perusahaan Manufaktur Yang Terdaftar Di BEI. 
Silfiani, S. (2018). Pengaruh Kepemilikan Institusional Terhadap Nilai Perusahaan Dengan Kebijakan Hutang Sebagai Variabel Intervening (Studi Empiris: Perusahaan Manufaktur Yang Terdaftar Di Bei Periode 2010-2015). Jurnal Akuntansi, 6(2).

Sari, Z. E. (2013). Pengaruh Profitabilitas, Leverage, Economic Value Added Dan Risiko Sistematis Terhadap Nilai Perusahaan (Studi Empiris pada Perusahaan Kategori LQ45 yang Terdaftar Di BEI). Jurnal Akuntansi, 1(2).

Sugiyono. (2016). Metodologi Penelitian Kuantitatif, Kualitatif, dan $R \& D$. Bandung: CV Alfabeta.
Hasnawati, S., \& Sawir, A. (2015). Keputusan keuangan, ukuran perusahaan, struktur kepemilikan dan nilai perusahaan publik di Indonesia. Jurnal Manajemen dan Kewirausahaan, 17(1), 65-75.

Wijaya, A. H. (2016). Pengaruh Return On Asset, Debt To Equity Ratio Dan Current Ratio Terhadap Nilai Perusahaan Sektor Manufaktur Yang Terdaftar Di Bei Periode 2010-2014. E-Jurnal Ekonomi dan Bisnis UMRAH, 1(3), 1-17.

(http://www.idx.co.id).

(htpp://www.finance.com). 